\title{
Xanthone from Garcinia eugenifolia (Clusiaceae)
}

\begin{abstract}
Studies on the twigs of Garcinia eugenifolia have led to the isolation of one xanthone 5,9dihydroxy-8-methoxy-2,2-dimethyl-7-(3-methylbut-2-enyl)pyrano[3,2-b]xanthen-6(2H)-one (1) and one triterpenoid, sitosterol (2). Meanwhile, studies on the leaves of Garcinia eugenifolia provided another triterpenoid, friedelin (3). The structures of these compounds were determined by spectroscopic methods such as 1H NMR, 13C NMR, mass spectrometry (MS) and by comparison with previous studies. The hexane and ethyl acetate extracts of Garcinia eugenifolia indicated strong cytotoxicity towards the HL-60 cell line with IC50 values of $1.9 \mathrm{\varepsilon g} / \mathrm{ml}$ and $2.5 \mathrm{gg} / \mathrm{ml}$ respectively. However, the methanol extract gave moderate inhibitory activities (IC50<10 $\varepsilon \mathrm{g} / \mathrm{ml}$ ) towards HL-60 cell line.
\end{abstract}

Keyword: Garcinia eugenifolia; Xanthone; Cytotoxicity 